\title{
Віталій Терлецький
}

\section{МЕЖІ Й МОЖЛИВОСТІ МЕТОДУ ДОСЛІДЖЕННЯ КОНСТЕЛЯЦЙ}

Будь-яка інтерпретація філософський текстів повинна відповідати максимі трьох «К»: бути консеквентною, когерентною та конгеніальною. Той, хто зважується на тлумачення, має послідовно та цілеспрямовано скеровувати читача на певний, досі неторований, шлях. Поступування на цьому шляху має бути не стрибкоподібним, а крок за кроком виваженим, тобто зв'язним ходом думки; а задум, що постійно спрямовує цей рух, має бути якось суголосним ідеї автора першотвору.

Запропонована Віктором Козловським інтерпретація Кантової антропології [Козловський, 2014] ${ }^{1}$, здається, претендує на те, щоб відповідати такій максимі. Адже перед нами грунтовне, оригінальне та, певною мірою, амбітне дослідження антропологічного дискурсу Канта, в якому добре поєднана сумлінність копіткого історикофілософського аналізу із креативністю, що властива справжній філософської праці. Раніше вже була нагода представити доробок п. Козловського ширшому загалові, на підставі чого є змога довідатися про структуру й головні змістовні моменти цього непересічного для сучасної української науки дослідження [Терлецький 2015: 6771]. Тому в подальшому ми не повторюватимемо змісту книжки. Натомість на часі звернути увагу на ті позиції дослідника, які виявляються дещо проблематичними i стосуються передусім поняття «антропологія» й методології «дослідження констеляцій». Окремо варто увиразнити й результативну частину інтерпретації.

Як натякає вже заголовок книжки пана Козловського і як неодноразово підкреслює сам автор, йдеться про Кантове розуміння людини, ії природи, сутності й призначення, одне слово: про «антропологічний дискурс» кьонігсберзького філософа. При цьому подібний задум реалізується в такий спосіб, що інтерпретатор накреслює різні «моделі» цього дискурсу, послуговуючись усім можливим багатством матеріалу як творів самого Канта, так і великої дослідницької літератури. Хоча праця Канта «Антропологія з прагматичного погляду» (1798) постійно залишається в полі уваги, але, як небезпідставно наголошується, цієї уваги не достатньо для того, щоб розкрити повною мірою «основні виміри Кантового розуміння людини» (с. XXVI). 3 огляду на той факт, що людина - це і природна, і ментальна, і космополітична, і моральна, i, зрештою, інтелігібельна істота, до дослідження притягуються відповідні тексти і твори, релевантні виокремленим ракурсам. А проте, і формула заголовку «Кантова

(C) В. Терлецький, 2016

${ }^{1}$ Надалі посилання на монографію п. Козловського подаються у круглих дужках із зазначенням лише номерів сторінок. 
антропологія...», і численні твердження, що містять поняття «антропологія», спонукають до питання: який зміст вкладав Кант у поняття «антропологія»?

У праці «Антропологія з прагматичного погляду» сам Кант чітко визначає антропологію як «систематично укладене вчення про знання людини», а далі поділяє це вчення на «фізіологічну антропологію», що досліджує природу людини, i «прагматичну антропологію», спрямовану «на те, що людина, як істота, яка свобідно вчиняе, робить або може й повинна робити із самої себе» [Kant 1900 sqq.: VII, 119]2.

У вступі до «Метафізики звичаїв» (1797) Кант мовить про «моральну антропологію», яка «мала б містити лише суб'єктивні, як завадні, так і сприятливі умови виконання законів метафізики звичаїв у людській природі...» (АA VI, 217). Але з подальшого викладу стає зрозуміло, що філософ тут чітко розмежовує антропологію й моральну філософію - теза, яка добре відома також з інших праць. I в цьому контексті, й у зв'язку з іншими дефініціями чи описами «антропології», сам Кант виразно заявляє про досвідний характер цього вчення, що зумовлено емпіричними «засобами» цієї дисципліни: «подорожі», «спілкування з людьми» й «загальне знання людини», яке походить із «внутрішнього досвіду» (AA VII, 120).

Щоправда, із таким емпіричним і прагматичним характером Кантової антропології дещо не узгоджується відома теза філософа, що три кардинальні питання філософії можуть бути зведені до питання «Що є людина?» (AА XI, 414; cf. IX, 25). Більш за те, в одному пасажі з епістолярної спадщини Кант повідомляє Марку Герцу про свій задум чогось на кшталт трансцендентальної антропології: «Задум, який я маю, полягає в тому, щоб через неї [антропологію] відкрити джерела всіх наук...» (АА X, 145). Утім, як відомо, Кант у 1781 р. розгорнув концепт не трансцендентальної антропології, а трансцендентальної філософії. Можливо, це сталося через те, що антропологія як дисципліна, яку він одним із перших інституційно закріпив у академічному середовищі Німеччини, завжди межувала 3 фізичною географією й емпіричною психологією. Отже, поняття «антропологія» в Канта має чітко окреслене й зафіксоване значення, це «вчення» має відповідний статус і займає певне місце в ієрархічній системі наук і «дисциплін розуму».

У зв'язку з цим можна констатувати певну проблематичність між тим, що мав на думці під «антропологією» Кант, і тим, як кваліфікує «антропологічний дискурс» інтерпретатор, коли, наприклад, зазначає: «Цей дискурс передбачає і потребує виявлення значно ширшого кола ідей та концептів, які стосуються тих тематичних сфер дослідження, які не охоплюються ані трьома "Критиками”, ані його книжкою і лекціями $з$ прагматичної антропології» (с. 41-42). Інтенція інтерпретатора in genere збагнена, бо ж мається на увазі дослідження й тлумачення усього спектру визначень $\mathrm{i}$ характеристик людини, що трапляються в Euvre Канта. Однак відкритим залишається питання, який стосунок усе це має до антропології in sensu strictiore? Можливо, доречніше було б назвати дослідження на кшталт «Кантів антропологічний дискурс» або, традиційніше, «Кантове вчення про людину», що точніше відповідало б задуму інтерпретації й не провокувало б якихось двозначностей.

На підставі методологічного поєднання «концептуального моделювання» й «дослідження констеляцій» п. Козловський реконструює п’ять різних моделей Кантового антропологічного дискурсу. За логікою викладу, ці моделі поступово й із різних боків

\footnotetext{
2 Надалі посилання на це видання подаватимуться у круглих дужках із зазначенням абревіатури АА (=Akademie-Ausgabe), номера тому римською цифрою та номера сторінки арабською цифрою. При цитуванні першої «Критики» вказані сторінки другого видання 1787 р.
} 
висвітлюють об’єкт дослідження: спершу як homo naturalis, потім як homo mentalis, далі як homo cosmopoliticus, далі як homo moralis i, нарешті, як homo intelligibilis. Для побудови саме таких моделей і в саме такій послідовності вирішальну роль відіграли, як твердить дослідник, три «констеляції» чи «хронотопи-події»: 1) вольфіанство (мало значення для переосмислення Кантом усієї філософії, включно з антропологією); 2) певні ідеї Готфрида Вільгельма Ляйбніца (особливо, про «живі» й «мертві» сили); 3) механістична Ньютонова картина світу як взірець науковості як такої (с. 62-63). Звісно, запропоновані констелятивні моделі Кантового розуміння людини не детермінують одна одну, не виведені вони й із якогось одного-єдиного принципу. Вони, радше, певним чином співвіднесені або синхронізовані одна з одною. Втім, остання модель людини як «нормотворчої та інтелігібельної істоти» (с. 396-426) все ж постає якимось логічним довершенням чи кульмінацією реконструкції, що можна розцінювати і як результат дослідження, що виходить за межі суто антропологічного дискурсу та переводить до царини «постантропології» (с. 425). Оскільки тут ми маємо завершальну ланку інтерпретації Кантової антропології, яка, з одного боку, витримана в дусі критицизму, а, з іншого, засвідчує свій інноваційний характер, є сенс докладніше зупинитися на специфічній конфігурації цієї моделі.

Як натякає вже сама подвійна назва моделі, вона поєднує два тематичні блоки: нормотворчість й інтелігібельність.

Спершу увага зосереджується на Кантовому концепті «антропономія» й на його оцінці деякими давнішими та сучасними інтерпретаторами. Це поняття, справді, є ӓл $\alpha \xi$ $\lambda \varepsilon \gamma o ́ \mu \varepsilon v o v$ у творах Канта, а те єдине місце, де воно трапляється в «Метафізиці звичаїв» (АA VI, 405-406), має певне значення для антропологічних поглядів філософа. Антропономія тут недвозначно протиставляється антропології: якщо остання спирається на досвід («що є люди тепер, чим вони були й чим вони будуть»), то перша «встановлюється безумовно законодавчим розумом». Кант докладніше не експлікував це поняття, тому дослідники різних часів намагалися якось тлумачити його в ширшому контексті. Запропоноване п. Козловським визначення «антропономії» (с. 398) включає автономність і нормативність (законодавчість) людського розуму в проекції на сферу політичного життя. Власне, мається на увазі політично-правовий характер Кантової антропономії. Як підсумовує дослідник, застосований до антропологічної тематики «антропономічний вимір людини уможливлює гомогенність і передбачуваність політичного життя людей на засадах не рабської покори, а свободи й гідності людини». Людина при цьому постає конституентою «політично-правого порядку спільного людського світу» й тим самим вона, як громадянин, вступає у відносини з правовою державою (с. 403-404).

Що стосується цього сюжету інтерпретації, то він настільки ж нетривіальний, наскільки ж комплементарний. Насамперед варто констатувати, що запропонована експлікація антропономії як «законодавчого розуму», що має на меті політичноправову царину вжитку, у цілому розгортається в межах такого тлумачення, яке подав свого часу Герман Коген. Інтерпретація ж антропономії, викладена в розвідці Уве Венцеля, хоча і згадується (с. 400), але в далеко не повному обсязі. Справді, в основі згаданої розвідки лежить поняття людини як «мети самої по собі». Але водночас Венцль при трактуванні антропономії виявляє «констеляцію» потрійної структури в Канта, яка містить такі основні елементи: «фактичність підпорядкованості законові - спонтанність самозаконодавства - нормативність самостосунку» [Wenzel 1992: 277]. I всі ці три моменти, на думку німецького дослідника, якраз і зібрані в «цілому визначенні людини», про яке говорить Кант у першій «Критиці» [Kant 1998: 
868]. Як видається, врахування здобутку цього тлумачення, що обстоює тезу про взаємну імплікацію визначення людини й само-визначення, можливо, надало б інших нюансів конфігурації п'ятої моделі людини.

Справа в тім, що політично-правова перспектива антропономії слабко в'яжеться 3 моделлю homo intelligibilis. Адже мається на увазі публічна, громадянська сфера, в якій виявляє себе законодавство розуму й до якої воно має застосовуватися. У такому разі антропономічна модель людини, якщо тільки зважитися на такий концепт, має бути локалізована на межі між космополітичною й моральною моделями, бо тільки там можливе поєднання простору реалізації з певними нормативними принципами. Але, auctor dixit.

Утім, в інтерпретації п. Козловського модель людини як інтелігібельної істоти все ж пов'язується із засадничим розмежуванням емпіричної й інтелігібельної природи. Цілком слушно зауважуючи, що значення цього розрізнення не вичерпується лише моральним вченням філософа, дослідник спочатку окреслює інтелігібельну природу (характер) як певну властивість «автономного суб'єкта», яка полягає в можливості «започатковувати ті події, які без його участі не могли б з'явитися в світі» (с. 406). Подальше пояснення цього поняття здійснюється шляхом увиразнення його зв'язку із простором і часом як формами чуттєвого споглядання та через висвітлення «метатеоретичної функції» поняття «кожна розумна істота». До цього тематичного кола долучені цікаві міркування Пітера Стросона про кореляцію між «іншістю» форм чугтєвого споглядання та «іншістю» інтелектуальних структур. Не менший теоретичний інтерес являє собою теза дослідника, згідно з якою концепція часу Джона Мак-Тегорта (J. M. MacTaggart) $з$ iï вже класичним розрізненням «серії А» й «серії В» приховує кантівські мотиви. Щоправда, слід зазначити, що авторський виклад тут інколи губиться в різних традиціях трактування Канта. Наприклад, у Якко Гінтіки, Пітера Стросона й Альберта Айнштайна ми маємо три істотно різні підходи до тлумачення простору й часу як форм чуттєвого споглядання та їхньої ролі в математиці й природничій науці. Звичайно, це в жодному разі не применшує потужної просвітницької функції запропонованої інтерпретації.

При наступному кроці в експлікації інтелігібельної природи ключовими поняттями постають спонтанність і свобода. Небезпідставно наголошуючи, що поняття свободи для Канта важить значно більше, ніж просте визначення людської волі (свобода волі), п. Козловський стверджує, що це поняття є певним «трансцендентальним принципом», умова якого - саме ноуменальна природа. Звісно, свобода як ідея розуму не підвладна теоретичному пізнанню, наша суб' єктивність на рівні чуттєвості й розсуду не конституює ii як предмет. І все ж, попри неспроможність пізнання свободи, ми маємо певний «досвід свободи», який уможливлюється завдяки спонтанності. У зв'язку з цим інтерпретатор висуває таку тезу: «Спонтанність, як найгрунтовніша характеристика свободи, уможливлюється наявністю інтелігібельної природи, і без спонтанності вона (свобода) неможлива» (с. 419). Докладніший аналіз спонтанності показує ії значущість передусім у практичній площині, де йдеться про вчинки людини як розумної істоти та, зрештою, як особи. Адже мається на увазі спроможність «самопокладати “причиновий ряд” поза будь-якими емпіричними залежностями», тобто мовиться про самовизначення людини щодо тих підстав, спираючись на які вона вчиняє як свобідна істота. Кардинальним принципом усього ходу думки є те, що саме інтелігібельна природа $є$ глибшим підгрунтям свободи людини, виявлюваної через спонтанність. Хоча ця ноуменальна сфера закрита для аподиктичного пізнання, однак людина все-таки може мислити ії як певний регулятив, у «модусі немовби». На підставі цього п. Козловський робить висновок, що «Кантове вчення про 
інтелігібельну природу долає антропологічний дискурс і веде до значно глибшого розуміння людини» (с. 424). Провідна роль тут належить метатеоретичній тезі про «кожну розумну істоту», якій властивий інтелігібельний характер. Долаючи «досвід людини», Кантова думка виходить за межі такого дискурсу і приводить до «постантропології» (с. 425). Хоча в критичній філософії годі шукати ії конкретизації, проте, на думку дослідника, той факт, що ми спроможні мислити ноуменальну природу, виявляє певні обриси такої «метатеоретичної конструкції».

Певна річ, при всій складності висвітлення ролі й функції «інтелігібельного» в критичній філософії, доречно було би вдатися до екзегетичного витлумачення цього поняття у зв'язку з поняттями «природа» й «характер». Питання в тому, чи еквівалентні поняття «інтелігібельна природа» й «інтелігібельний характер». Крім того, не зайвим було б розгорнуто представити Кантові спроби увиразнення «інтелігібельного характеру» 3 першої «Критики», особливо такі його риси, як суб'єктність, діяльність, позачасовість, каузальність [Kant 1998: 566-586]. Що стосується спонтанності, то, 3 огляду на стратегію дослідження - зважати на релевантні постаті цілої традиції кантіанства, - викликає подив неврахування парадоксу схоплення чистої діяльності (спонтанності), виявленого Йоганом Готлібом Фіхте у «Другому вступі до вчення про науку». На жаль, поза рамцями дослідження залишився теологічний контекст Кантової тези про спонтанність (свободу). Після інтерпретації Гайнца Гаймзьота в його новаторській статті «Метафізичні мотиви у формуванні критичного ідеалізму» (1924), де продемонстровано, зокрема, що поняття Бога й свободи відіграли вирішальну роль у формулюванні тези про ідеальність (нереальність) часу, видається недоречним нехтувати таким здобутком, надто при експлікації інтелігібельної природи.

Хоча низку потенційних «вдосконалень» можна й продовжити, все ж це побажання суб'єктивне. Утім, відкритим залишається принциповіше питання: чи можна послуговуватися поняттям інтелігібельна природа як ultima ratio при тлумаченні Кантового антропологічного дискурсу, точніше - однієї з його моделей? Ще більшої ваги набуває інше питання, яке, здається, тісно пов'язане з попереднім пунктом. Якщо поняття «антропологія» в Канта чітко окреслене, то концептуальна модель людини як інтелігібельної істоти, що реконструюється на підставі певних текстів і контекстів думки, per definitionem безвідносна до цього поняття. Узгодженість між програмою інтерпретації, зазначеною в заголовку, і фактично здійсненим тлумаченням видається досить сумнівною.

Питомою рисою дослідження п. Козловського, що уможливила його продуктивність і оригінальність, є експліцитна рефлексія над методологічним підгрунтям тлумачення думки Канта, іiі історичного контексту та широкого спектру іiї наступної рецепції. Як вище відзначалося, завдяки сполученню «концептуального моделювання» із «дослідженням констеляцій» вдається по-новому поглянути на все розмаїття Кантових спроб відповісти на питання «Що є людина?». Якщо концепт «моделювання» дістав цілком достатнє обгрунтування як методологічний інструмент аналізу (с. 47-59), то «дослідження констеляцій», відповідно, «концепт констеляції», витлумачений таким чином, що вимагає певного уточнення й поглиблення.

Позиція дослідника щодо поняття «констеляції» в тезовому вигляді така:

- констеляції схарактеризовані як «збіги обставин»: інтелектуальних, соціальних, політичних, релігійних тощо (с. 60); 
- далі констеляції конкретизуються як «локальні хронотопи», що об’єднують «сингулярність місця» й «конкретність часу» певної події (с. 61);

- водночас концепт констеляцій означає «методологічний прийом», що розцінюється як альтернатива до концепту «впливу» (с. 59); власне, тут маються на увазі не самі констеляції in concreto, а їх дослідження;

- цей прийом описується як «...уважний аналіз тих інтелектуальних, психологічних, соціальних обставин, які не детермінують, а, так би мовити, “втягують” дослідника, його пошуки у своє смислове поле, що постає, як найближче середовище, яке для філософа чи науковця розкривається як його світ» (с. 60).

В. Козловський переконаний, що «тенезу кантівського філософування можна добре описати за допомогою саме цього методологічного прийому» (с. 60). Заразом він зазначає, що констелятивне значення має не лише вольфіанство, яке разом із ідеями Ляйбніца й механістичною картиною світу Ньютона утворюють три «концептуальні хронотопи», а й рідне місто філософа Кьонігсберг упродовж правління ліберального Фридриха II (с. 60-61). Зрештою, у підсумку методологічна рефлексія набуває такого формулювання: «Ці констеляції увиразнюються у вигляді певних подій, що супроводжували інтелектуальне життя Канта, подій, в осерді яких він опинився ще на початку свого становлення як науковця і філософа - дослідника природи, розробника підходів у царині наукового та філософського пізнання» (с. 63).

Оскільки таке переконання інтерпретатора Кантової антропології є досить новаторським, принаймні ніхто досі не застосовував методологію дослідження констеляцій до реконструкції Кантового антропологічного дискурсу, варто спеціально зупинитися на її своєрідності.

Хоча поняття «констеляція» спершу й було суто астрологічно-астрономічним i означало певне взаємне розташування зірок з погляду спостерігача на Землі, проте на сьогодні воно увійшло до корпусу гуманітарних наук, де постає вже якоюсь комплексною методологічною програмою. У соціології і психології, у літературознавстві й постструктуралізмі, в історії й політичних науках послуговуються поняттям «констеляція», яке загалом вказує на «багатозначну структуру відношення, тобто ансамбль різних (політичних, економічних або культурних) позицій і факторів, які принаймні у сприйнятті спостерігача - утворюють динамічний, змінний зв'язок дії й можуть бути пояснені або зрозумілі також лише на підставі цього реляційного зв'язку» [Albrecht 2010: 107].

У філософії чи, вужче, в історико-філософському дослідженні, це поняття теж набуло активного вжитку в останні десятиліття. Щоправда, тут ідеться вже про поняття «дослідження констеляцій» (Konstellationsforschung). В. Козловський слушно зауважує, що методологія дослідження констеляцій з'явилася 30-40 років тому й пов'язана iз постаттю Дитера Генриха, чиї розвідки на ниві «циркуляції ідей кантівської філософії» мають вагоме значення для цієї методології. Власне, йдеться про започаткований Генрихом проект дослідження ранньої фази німецького ідеалізму, мета якого полягає у виявленні й дослідженні певних спільних «мисленнєвих просторів» (Denkräume), в яких присутні різні мислителі, що активно взаємодіють між собою, і результатом такої взаємодії є не лише опубліковані філософські твори, а й дискусії та дебати, що супроводжують появу різних, інколи протилежних філософських проектів. Елемент конфлі- 
кту, який міститься в такій інтеракції й часто провокує певні «інтелектуальні розриви», цілком доречно відтінений українським дослідником (с. 62).

Появу на авансцені констелятивного аналізу спонукали різні мотиви. Насамперед це відмова від узвичаєних підходів історико-філософського дослідження, які послуговуються поняттями «впливу», традиції й біографії. Певне значення мало також небажання дослідників приставати до поширеного погляду, згідно з яким філософія - це великі імена й оприлюднені твори. А проте, не останню роль тут відіграла особистість Генриха. 3 такої настанови зрозумілий і вибір інструментарію дослідження: крім опублікованих творів, особлива увага прикута до щоденників, листування, нотаток, рецензій, рукописної спадщини загалом, записів лекцій. Певна річ, це передбачає опрацювання величезного обсягу матеріалу, що дає змогу здійснювати на мікрорівні реконструкцію «документів і аргументів» певного осередку мислителів (представників німецького ідеалізму). При цьому акцент робиться на з'ясуванні і предметів дискусій, і їхньої тривалості, адже саме вони часто накреслювали той горизонт, в якому тільки і змогли постати оригінальні філософські проекти.

Слід зазначити, що представники цього напряму дослідження вбачають такі специфічні риси констеляцій: дуже щільний взаємозв’язок між особами, ідеями, проблемами й теоріями; наявність динамічної комунікації між усіма цими факторами; така динамічність зумовлює появу відповідних філософських позицій або розв'язків проблем.

Утім, сам Генрих програмно відокремлює два види констеляцій: «констеляції між поняттєвими і системними утвореннями великих теорій» і «констеляції філософського діалогу, які мали значення, яке не можна ігнорувати, для формації систем після Канта й Фіхте, а також, мабуть, для власного шляху Фіхте до Єни й далі Єни». Зрозуміло, що обидва види констеляцій мають відповідні методи пізнання. Якщо для першого типу відповідним $є$ «аналіз аргументів і поняттєвих форм», то для другого адекватним $є$ «метод історичного дослідження джерел» [Henrich 1991: 42]. Це суттєве уточнення завжди має залишатися в полі зору як прихильників, так і критиків констелятивного аналізу.

Дослідники констеляцій запевняють, що формування перших етапів післякантівської філософії було констелятивно уможливлено й, відповідно, його не можна вповні й достатньо виявити, спираючись лише на опубліковані тексти цих мислителів. Вагомим моментом у цьому процесі $є$ те, що для німецьких ідеалістів сталим вихідним пунктом завжди поставала трансцендентальна філософія Канта, точніше - ii проблематичність як у плані суб'єктивного обгрунтування на рівні теорії, так і 3 огляду на відкритий конфлікт із позицією ортодоксальної теології (для Гьольдерліна, Гегеля й Шелінга, як студентів теологічного семінарію Тюбінгенського університету, цей конфлікт був добре відомий через тутешнього професора Йогана Фридриха Флята, котрий в 'їдливо критикував Канта).

Вище накреслені штрихи розглядуваної методологічної програми, у жодному разі не претендуючи на її цілковитий опис, все ж дають змогу збагнути те, про що йдеться, і водночас зіставити іiї задум і спрямованість із тим, як п. Козловський трактує констеляції та їх дослідження.

Насамперед слід констатувати, що дослідник значною мірою використовує не лише оприлюднені твори Канта, а й епістолярну спадщину та, що головне, записи лекційних курсів філософа. Що стосується рецепції Кантової філософії, то й у цьому пункті п. Козловський, здається, дотримується настанови констелятивного аналізу, коли, наприклад, відтворює історію сприйняття і трансформації критицизму чи то у 
психологічно-антропологічному (Шмід, Фріз, Апельт), чи то у прагматично-антропологічному річищах (с. 275-286, 310 sqq.). Спеціально увиразнено деякі епізоди цієї рецепції, що мали місце ще за життя філософа й вирізняються яскраво дискусійним і полемічним характером, наприклад, відома полеміка з Йоганом Готфридом Гердером (c. 238-242) і несправедливо знехтувана дискусія з вольфіанцем Йоганом Августусом Ебергардом і осередком часопису «Philosophisches Magazin» (c. 489-499). У таких конфліктних контекстах і проявляється позиція дослідника констеляцій. Щоправда, прикрим є той факт, що у випадку суперечки з Ебергардом п. Козловський лише відтворив закиди останнього проти критичної філософіï, але не здійснив in extenso реконструкцію «документів і аргументів», передусім відповіді Канта у праці «Про одне відкриття...» (1790). І ця обставина досить показова, бо вона засвідчує, що дослідження часто не виконується шановним автором саме на мікрорівні, не піддається прискіпливому аналізові та динаміка, якої набуває конфігурація теорії (критичної філософії) перед, під час і після зіткнення з іншою теорією та ії поняттєвістю. Адже момент динамічності, мабуть, найвагоміший у дослідженні констеляцій.

Але, як програмно вказує Генрих, існують «констеляції філософського діалогу», тобто дійсної комунікації між його учасниками. Якщо такий вид констеляцій документально зафіксований і вповні прийнятний при аналізі початкових етапів німецького ідеалізму, то у випадку Кантової філософії його валідність стоїть під питанням, бо ж ми позбавлені відповідних надійних документальних свідчень як джерельного підгрунтя для дослідження. Крім листів, нотаток у щоденниках, як і заміток властиво філософського характеру, вагому роль відіграють живі розмови між особистостями, які зі свого боку накладають відбиток на «подумане» й «написане». Звичайно, дистинкцію між двома видами констеляцій припустимо розцінювати як суто теоретично вмотивовану конструкцію, на яку можна й не зважати при дослідженні констеляцій Кантової філософії. Проте неусувним питанням залишається те, що розуміти під констеляцією.

Виокремлені й проаналізовані п. Козловським три вказані констеляції, на наш погляд, такими не $\epsilon$ essentialiter. По-перше, усі ці «хронотопи-події» добре відомі й так чи так описані істориками Кантової філософії, які дуже далекі від методології дослідження констеляцій. Вплив зазначених «хронотопів-подій» на Канта незаперечний, і так само безперечна Кантова оригінальність як 3 певного часу самостійного мислителя на їхньому тлі. По-друге, констеляції як «динамічні структури» припускають активну взаємодію учасників діалогу, обмін думками, полеміку, зміну попередніх поглядів унаслідок такої інтеракції, тощо. Чи можна цю рису приписати виділеним «хронотопам-подіям», сказати складно. По-третє, констеляції - це, зрештою, штучні конструкти, які постали внаслідок реконструкції дослідника; їхня своєрідна ідеальність не дає змоги знайти точного референта в тій інтелектуальній атмосфері, в якій формувалася й розвивалася Кантова думка.

Якщо прийняти таке тлумачення констеляцій, то, можливо, не варто ототожнювати це поняття з виокремленими «концептуальними хронотопами». Утім, заради справедливості слід визнати, що у своєму дослідженні п. Козловський комбінує дослідження констеляцій з «концептуальним моделюванням», причому, як неодноразово зазначалося, у самій інтерпретації вага лежить саме на певних «моделях людини», реконструйованих на підставі Кантового дискурсу. Втім, таке досить своєрідне використання «методологічного прийому» дослідження констеляцій спонукає до більш принципового питання: чи обмежено дослідження констеляцій лише раннім німецьким ідеалізмом, чи його можна плідно використати і для інших етапів, періодів і персоналій філософії? 
Прихильники цієї амбітної програми вважають за можливе таке розширення, наприклад, Сара Гатен веде мову про констеляцію в осередку кембридзьких платоніків [Muslow... 2005: 340-358]. Однак серед сучасних істориків філософії, які також обстоюють принципи докладного й немов мікроскопічного аналізу, домінує певна стриманість щодо такої можливості. Проблематичною видається сама методологічна стратегія такого типу дослідження, бо ж констеляції, про які тут ідеться, є результатом реконструкції, на них вибудовуються певні тези. Однак чи можуть останні правити за «предмет філософської дискусії»?. Ще більш гострим стає питання про конкретні результати «дослідження констеляцій для інтерпретації великих текстів німецького ідеалізму, задля роз'яснення яких колись і з'явилося це дослідження» [Gutschmidt 2007: 11]. Мабуть, складнішим є питання про можливість застосування констелятивного аналізу в рамцях дослідження Кантової філософії, оскільки, за задумом, воно стосувалося дослідження саме післякантової філософії. Визнаючи його інноваційний характер in toto, сучасні кантознавці вагаються послуговуватися цим методом через той «філософсько-систематичний інтерес», що лежить в його основі. Так, Лутц-Генінг Піч при дослідженні динаміки рецепції і критики Кантової філософії в невеликий проміжок часу між публікаціями першої і другої «Критик» дотримується тієї методологічної настанови, що ніби підсилює включеність «визнання Кантового вчення в історичний контекст тогочасних дискусій» і зображує «їх із власної перспективи часу як відкритого процесу...» [Pietsch 2010: 5]. Звісно, акцент тут зроблений на тому, що умовно може підпадати під другий вид констеляцій, але $з$ тим застереженням, що не здійснюється реконструкція «філософського діалогу». Запропонована п. Козловським інтерпретація Кантової антропології $\epsilon$, наскільки нам відомо, першою спробою, яка наважується послуговуватися методом дослідження констеляцій при аналізі Кантового вчення.

\section{СПИСОК ЛІТЕРАТУРИ}

Козловський, В. (2014). Кантова антропологія: джерела, констеляиії, моделі. Київ: ВД Києво-Могилянська академія.

Терлецький, В. (2015). Український погляд на Кантову антропологію. Філософська думка, (2), 67-71.

Albrecht, A. (2010). «Konstellationen». Zur kulturwissenschaftlichen Karriere eines astrologischastronomischen Konzepts bei Heinrich Rickert, Max Weber, Alfred Weber und Karl Mannheim. Scientia Poetica, 14, 104-149.

Gutschmidt, H. (2007). Vernunfteinsicht und Glaube. Hegels These zum Bewusstsein von etwas «Höherem» zwischen 1794 und 1801. Göttingen: Vandenhoeck, \& Ruprecht.

Henrich, D. (1991). Konstellationen. Probleme und Debatten am Ursprung der idealistischen Philosophie (1789-1795). Stuttgart: Klett-Cotta.

Kant, I. (1900 sqq.). Gesammelte Schriften: Hrsg. von der Preußischen (Deutschen) Akademie der Wissenschaften. Berlin: Reimer, \& De Gruyter.

Kant, I. (1998). Kritik der reinen Vernunft (J. Timmermann, Hrsg.). Hamburg: Meiner.

Muslow, M., \& Stamm, M. (Hrsg.). (2005). Konstellationsforschung. Frankfurt am Main: Suhrkamp.

Pietsch, L.-H. (2010). Topik der Kritik. Die Auseinandersetzung um die Kantische Philosophie (1781-1788) und ihre Metaphern. Berlin, \& New York: De Gruyter.

Wenzel, U. J. (1992). Anthroponomie. Kants Archäologie der Autonomie. Berlin: Akademie Verlag.

Одержано 3.03.2016 


\section{REFERENCES}

Albrecht, A. (2010). «Konstellationen». Zur kulturwissenschaftlichen Karriere eines astrologischastronomischen Konzepts bei Heinrich Rickert, Max Weber, Alfred Weber und Karl Mannheim. Scientia Poetica, 14, 104-149.

Gutschmidt, H. (2007). Vernunfteinsicht und Glaube. Hegels These zum Bewusstsein von etwas «Höherem» zwischen 1794 und 1801. Göttingen: Vandenhoeck, \& Ruprecht.

Henrich, D. (1991). Konstellationen. Probleme und Debatten am Ursprung der idealistischen Philosophie (1789-1795). Stuttgart: Klett-Cotta.

Kant, I. (1900 sqq.). Gesammelte Schriften: Hrsg. von der Preußischen (Deutschen) Akademie der Wissenschaften. Berlin: Reimer, \& De Gruyter.

Kant, I. (1998). Kritik der reinen Vernunft (J. Timmermann, Hrsg.). Hamburg: Meiner.

Kozlovsky, V. (2014). Kant's Anthropology: sources, constellations, models. [In Ukrainian]. Kyiv: Kyiv-Mohyla Academy Press.

Muslow, M., \& Stamm, M. (Hrsg.). (2005). Konstellationsforschung. Frankfurt am Main: Suhrkamp.

Pietsch, L.-H. (2010). Topik der Kritik. Die Auseinandersetzung um die Kantische Philosophie (1781-1788) und ihre Metaphern. Berlin, \& New York: De Gruyter.

Terletsky, V. (2015). Ukrainian Point of View on Kant's Anthropology. [In Ukrainian]. Filosofska dumka, (2), 67-71.

Wenzel, U. J. (1992). Anthroponomie. Kants Archäologie der Autonomie. Berlin: Akademie Verlag.

Received 3.03.2016

\section{Vitali Terletsky}

\section{Boundaries and Possibilities of the Constellation Research Method}

The study of Kant's anthropology, proposed by Viktor Kozlovskyi in its original and thorough monograph, is an entirely new interpretation of Kant's answer to the fundamental question "What is man?”. On the basis of the philosopher's heritage and taking into account the large body of research literature, Kozlovskyi reconstructs five conceptual "human models" in Kant's anthropological discourse. However, this study contains a number of problematic statements and conclusions. I argue first, that there is some inconsistency between Kant's understanding of the concept of "anthropology" and Kozlovskyi's explanation. Second, the model of man as intelligible being, made explicit through the concepts of "freedom" and "spontaneity", is a justified construction within the limits of criticism, but not quite correct with regard to the place and function of "anthropology" in it. Third, we can see a dissonance between Kozlovskyi's explanation of the constellations as "chronotopes-events" and interpretation of this concept by Dieter Henrich's school, where the methodology of "research constellations" was used to elucidate the early phase of German idealism. However, this leads to the cardinal question of how far this methodology is applicable for the analysis of Kant's philosophy.

Vitali Terletsky, PhD in philosophy, senior researcher, Head of the Philosophy and Geopolitics Department at the Research Institute of Ukrainian Studies.

Віталій Терлецький, канд. філос. н., старший науковий співробітник, завідувач відділу фiлософії та геополітики Науково-дослідного інституту українознавства.

Виталий Терлецкий, канд. филос. н., старший научный сотрудник, заведующий отделом философии и геополитики Научно-исследовательского института украиноведения.

e-mail: terletsky.vm@gmail.com 